
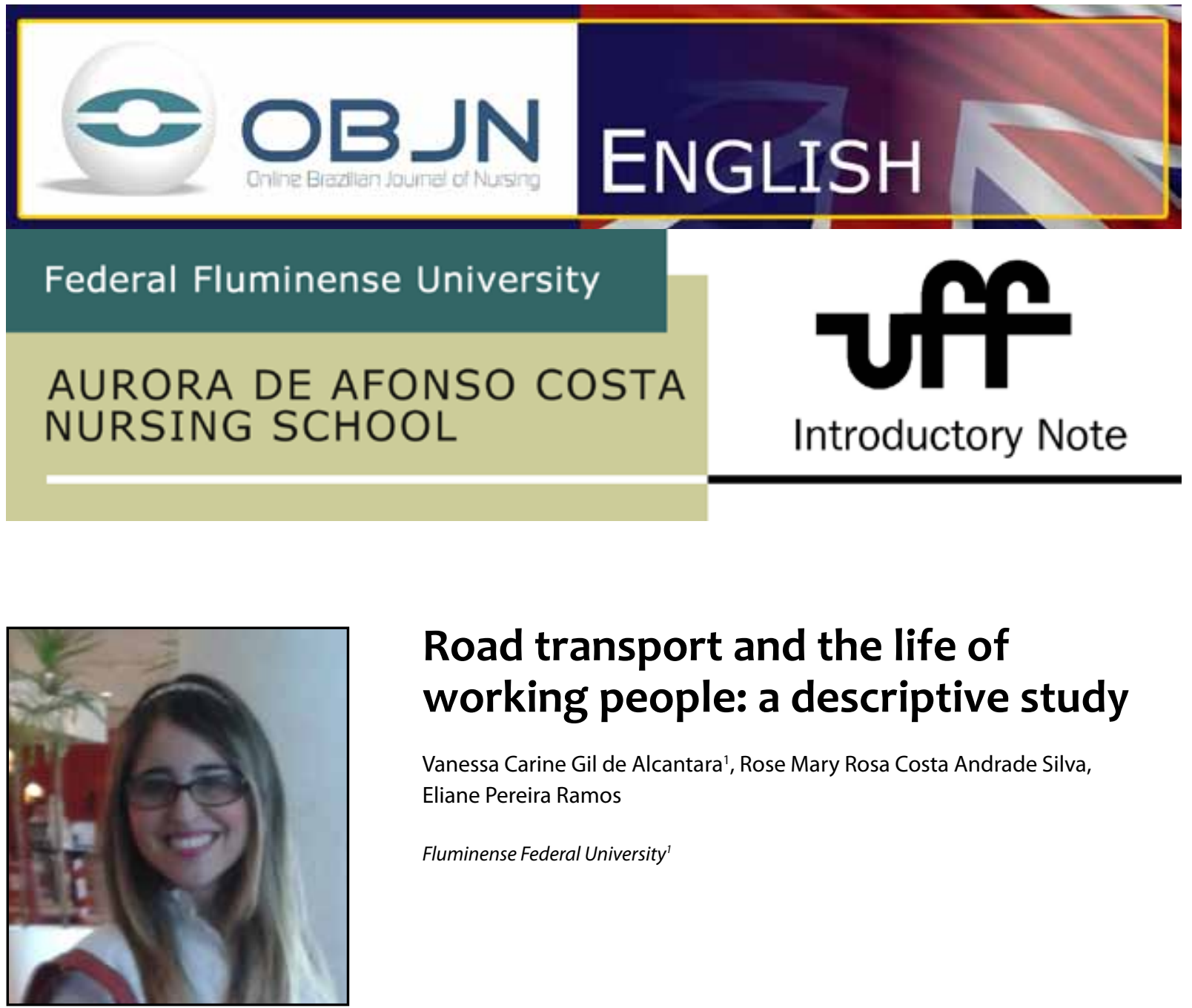

\title{
Road transport and the life of working people: a descriptive study
}

Vanessa Carine Gil de Alcantara1', Rose Mary Rosa Costa Andrade Silva, Eliane Pereira Ramos

Fluminense Federal University ${ }^{1}$

\section{ABSTRACT}

This is a dissertation project for the Academic Master's in Health Care Science, the theorization of knowledge and care practices.

Aims: To understand the impact on the health of individuals who work in public transportation (buses) with an emphasis on the views of drivers regarding their quality of life; to interpret what the bus drivers consider to be the "quality of life" that might be applicable to his routine; to propose measures to improve the quality of life of such individuals.

Method: this is a piece of non-experimental descriptive field research, in which we used a qualitative approach. It was performed in the Fluminense Region, on the east side of Rio de Janeiro. Interviews will be conducted in November and December 2013, targeting 250 bus drivers through the use of semi-structured interviews. The data will be treated with an emphasis on phenomenology based on the theories of Maurice Merleau-Ponty and Freud.

Descriptors: Nursing, Occupational Health, Quality of Life. 


\section{PROBLEM SITUATION AND ITS SIGNIFICANCE}

In 2012, the Urban Mobility law was enacted aiming to ensure the integration of transportation and allowing greater accessibility to the population that depends on this service. This law relates to the goals of the National Urban Mobility Policy, directs service regulations, guarantees the rights of users, presents the assignments of the Government Departments, guides the planning and management of the transportation system and provides tools to support mobility ${ }^{(1)}$. This study aims to understand the meaning of the quality of life (QOL) for public transport drivers in view of the need for sound urban mobility. QOL is multifactorial, and can be defined as the degree of pleasure and fulfillment in the life of an individual. For a high level of QOL, the basic needs of a person must be met to a certain extent. Working conditions and lifestyle greatly contribute to the promotion or otherwise of QOL, influencing the emotional and physical well-being of individuals ${ }^{(2)}$. The work that does not offer individuals the freedom necessary for them to use their skills in the performance of their activities results in some degree of dissatisfaction. Such dissatisfaction is a constructed defense mode. Making use of health and distorting the perceptions with regard to work are psychic tools that are established by the worker in the attempt to cope with the unbearable, the effects caused by work, due to the functional absence to psychism, often poor in meaning. With so many limitations imposed by contemporary society and by suffering at work, aid being provided to the worker is essential. Such assistance would not only motivate him, but would also provide him with the necessary quality of working condition. Studies on their lifestyle and the psychosocial factors to which they are subjected, are necessary for a macro- understanding of the ways in which these professional react regarding adverse conditions in terms of the work psychodynamics ${ }^{(3)}$. The road transport sector lacks practices and studies that can be used to interpret the symptoms of the subjects involved in this sector, which justifies the relevance of this study.

\section{GUIDING QUESTIONS}

What is the impact of daily work on the health of the individual who works in public transportation (buses)?

What does the bus driver consider to be "quality of life" concerning his routine?

What measures would improve the quality of life of such individuals?

\begin{abstract}
AIM
General

To understand the health impact of working condition on those individual who work in public transportation as bus drivers.
\end{abstract}

\section{Specific}

Discuss the perceptions of bus drivers concerning his routine with regard to his "quality of life" and;

Propose measures to improve the quality of life of such individuals.

\section{METHOD}

This is a descriptive piece of field research adopting a qualitative approach. This is because this is an attempt to understand the difficulties 
from the perspective of those who operate in a given context. In this case, we will consider the ways in which they deal with work, their grievances, emotions, feelings and desires. Regarding the use of research results or levels, this research is characterized as applied, as the researchers are driven by the need to deal with practical problems, find solutions for real issues, and consider the social context in which events occur. In this sense, the sample does not need to be random, nor particularly numerous. However, it is necessary to be cautious as to the recurrence of data and information. The target population consists of 250 bus drivers of a private company, located in the east fluminense district of Rio de Janeiro. Inclusion criteria: to be a bus driver employed the researched company, to have worked as a bus driver for at least six months and; agree to participate voluntarily in the study. Exclusion criteria: to be on vacation or leave of absence during the period of data collection or to be allowed to go back to work by the National Institute of Social Security (NISS) in less than six months. The final sample will be presented through data saturation. In the period from November to December 2013, interviews will be conducted based on a semi-structured script. The data will be dealt with using an emphasis on phenomenology based on the theories of Maurice Merleau-Ponty and Freud. The ethical aspects will be taken into account in accordance with Resolution 196/96.

\section{REFERENCES}

1. Brasil. Lei no. 12.587, de 3 de Janeiro de 2012. Institui as diretrizes da Política Nacional de Mobilidade Urbana e dá outras providências. Diário Oficial da União 4 Jan 2012.
2. Associação Brasileira de Qualidade de Vida [homepage in the internet]. Qual o significado de qualidade de vida no trabalho? [cited 2013 June 28]. Available from: http://www.abqv.com.br/ imprensa/Content.aspx?id=384.

3. Oliveira EB, Lisboa MTL. The impact of noise for the nursing workers health and the work process. Online braz j nurs [internet]. 2007 [Cited 2013 June 30]; 6(3): [about 3 p.]. Available from: http://www.objnursing.uff.br/index.php/ nursing/article/view/1237. doi: http://dx.doi. org/10.5935/1676-4285.20071237

Project Data: Dissertation project of the Academic Master's Program in Health Care Sciences, Fluminense Federal University (AMPHCS/FFU), adopted on December 13, 2012 by the examination board composed of Drs Rose Mary Rosa Costa Andrade Silva, Claudia Mara Melo Tavares and Valdecir Herdy Alves.

Ethical Considerations: This research project is part of Project Umbrella entitled: "Body issues in the healthcare context: a socio-cultural and philosophical approach in health and disease," approved by the Ethics Committee through the CAAE number 0155.0.258.000-11.

Advisor: Profa. Dra. Rose Mary Rosa Costa Andrade Silva

Co-Advisor: Profa. Dra. Eliane Pereira Ramos

Financial Support for the Research: own resources Mailing Address: Vanessa Carine Gil de Alcântara. Estrada dos Menezes, 400, Parque das Águas, Prédio Piratininga, apto 609. Alcântara, São Gonçalo, RJ. CEP 24710-095

E-mail: vanessagilpsicologa@hotmail.com

Received: $01 / 07 / 2013$

Revised: $24 / 07 / 2013$

Approved: 29/07/2013 